\title{
Knowledge and Attitude of Health Care Workers toward Human Immunodeficiency Virus Infection in King Abdulaziz Medical City
}

\author{
Fahad A. Al-Owais ${ }^{*}$, Mohammed S. Al-Abdullah², Adel F. Al-Othman² \\ ${ }^{1}$ College of Medicine, King Saud bin Abdulaziz University for Health Sciences, Riyadh, Saudi Arabia \\ ${ }^{2}$ Infectious Disease Division, Department of Medicine King Abdulaziz Medical City, Riyadh, Saudi Arabia \\ Email: f.a.h.a.d@live.com, msa816@gmail.com, othamna@ngha.med.sa
}

Received 25 May 2015; accepted 22 June 2015; published 26 June 2015

Copyright (C) 2015 by authors and Scientific Research Publishing Inc.

This work is licensed under the Creative Commons Attribution International License (CC BY).

http://creativecommons.org/licenses/by/4.0/

cc) (i) Open Access

\begin{abstract}
Background: Worldwide data shows that the stigma and discrimination for AIDS patients by health care providers have a negative impact on its epidemic. It discourages people from seeking care or being tested for HIV, thus reducing access to HIV/AIDS prevention. The study aims to evaluate the knowledge of the HCWs (health care workers) in King Abdulaziz Medical City about human immunodeficiency virus infection and their attitudes when they encounter HIV/AIDS patients. Methodology: A cross-sectional study was designed to collect data using self-administered structured questionnaire from 90 health care workers. It was distributed among HCWs in different wards in King Abdulaziz Medical City in Riyadh in August 2014. Results: The study included a total number of 90 heath care workers, of which 31 were physicians and 59 were nurses. Around $81(90 \%)$ of HCWs knew the causative agent for AIDS. Only $22(24 \%)$ of HCWs knew the level of risk of HIV transmission following needle stick injury. Most of HCWs 66 (73\%) knew that sexual practice was the most common mode of transmission. Around 27 (87\%) of physicians and $33(56 \%)$ of nurses were able to answer that antiretroviral therapy had the ability to control HIV-infection. In addition, $9(10 \%)$ of HCWs believed that AIDS was curable. Conclusion: It was obvious from our study that there was some amount of general information and knowledge with our HCWs. However, an educational campaign will try to increase the level of awareness and clear any misconception or misleading theories about HIV infection with our health care workers.
\end{abstract}

\section{Keywords}

AIDS, Stigma, Knowledge, Health Care Workers

\footnotetext{
"Corresponding author.
}

How to cite this paper: Al-Owais, F.A., Al-Abdullah, M.S. and Al-Othman, A.F. (2015) Knowledge and Attitude of Health Care Workers toward Human Immunodeficiency Virus Infection in King Abdulaziz Medical City. Advances in Infectious Diseases, 5, 87-93. http://dx.doi.org/10.4236/aid.2015.52010 


\section{Introduction}

HIV (Human immunodeficiency virus) is a lentivirus group that belongs to retrovirus family. Infection with HIV causes AIDS (Acquired immune deficiency syndrome), which is a syndrome characterized by progressive deterioration of the immune system, mainly affecting CD4 cells count. This makes the body more vulnerable to opportunistic infections and cancers [1]. The majority of the HIV infections are transmitted through body fluids, such as blood, semen, vaginal fluid, pre-ejaculate and breast milk. The vast majority of infections are due to sexual intercourse, and the most common route for children is vertical transmission (mother to child) [2]. HIV disease continues to be a serious health issue for parts of the world. Worldwide, about 35 million people are living with HIV, and in 2013, around 12.9 million people living with HIV were receiving ART (antiretroviral therapy) [3].

Saudi Arabia has a population of 29 million, of which 31\% are expatriates [4]. HIV/AIDS cases that have been reported to the Ministry of Health in Saudi Arabia were 10,217 from 2000-2009. The majority of the cases were non-Saudi individuals with an estimated number of 7216 (72\%), and the remaining were Saudi citizens with a number of 2956 (28\%). The overall average annual incidence was less than 4 cases per 100,000 of which 1.5 cases per 100,000 for Saudis and 13.2 cases per 100,000 for non-Saudis [5].

The three major cities where most of HIV/AIDS patients identified are: Jeddah, which has $40 \%$ of HIV/AIDS patients; Riyadh, which has $15 \%$ of the cases; Dammam, which has $12 \%$ of the cases [6]. The most common mode of infection in Saudi Arabia was heterosexual sex [7].

Saudi Arabia is considered as a very conservative country, which its values and beliefs are strictly based on Islam, when it is compared with other Muslim countries. The society in Saudi Arabia perceives AIDS as a moral disease, and they see people with HIV/AIDS as deviant and they deserve the disease because they violate the social and the religious rules that society believes in [8]. Stigma and discrimination for people who are living with HIV by health care providers, have a negative impact on the HIV epidemic. It discourages people from seeking care or being tested for HIV thus reducing access to HIV prevention [9]. Education about HIV/AIDS is essential to ensure that all HCWs (health care workers) have appropriate attitude and knowledge linked to HIV/AIDS.

In Nigeria, a cross-sectional study showed that the majority of the respondents did not know the causative agent of AIDS. Some of the respondents were unwilling to have voluntary counseling and testing for the possible reasons: fear of stigma, marital disharmony, incurable nature of the disease, and cost of treatment [10].

In a cross-sectional study, which was carried out in a nursing school of a Technological Educational Institute in Greece, a deficit of knowledge about routes of transmission was observed among nurses [11].

The study aims to assess the knowledge and attitude of the health care workers toward HIV patients in King Abdulaziz Medical City-Riyadh.

\section{Methodology}

A cross-sectional study of health care workers in King Abdulaziz Medical City in Riyadh was conducted. A questionnaire (Appendix) which contained 15 questions of different levels of information about HIV was formed. Then, a pilot study was done to assess the clarity and receive feedback and incorporate any modification. A finalized questionnaire was generated with no modification. The questionnaire contains four questions about demographics and 11 questions of knowledge and attitude about HIV/AIDS. The questions were focused on the cause of AIDS, mode of transmission, risk of needle stick injury, confidentiality, controlling and managing AIDS patient.

Approval was taken for the study from KAIMRC/IRB. Then a letter was sent to the chairman of medicine department asking permission to conduct the study with the health care workers. The questionnaire has no request about personal information or identification to insure confidentiality. Completion and submission of the questionnaire is considered consent to participate in the study.

The questionnaire was distributed among different wards in different days, time and numbers of study subjects chosen by the principal investigator in a period of four weeks in August 2014. The sample size was 90 health care workers including physicians and nurses, with a margin of error of $10 \%$ and confidence level of $95 \%$. Calculation was done using an online sample size calculator (http://www.raosoft.com/samplesize.html). The inclusion criteria were any physician and nurses. The exclusion criteria were other paramedical workers.

After collecting the data, we coded and entered the variables into an excel sheet then transformed into SPSS 
software. Then we subjected them to univarite analysis using the expert opinion on biostatistics. The mean, frequency, baseline characteristic were calculated. Chi-square test and t-test were calculated.

\section{Results}

The study included a total number of 90 health care workers, 66 (73\%) of them were females and 24 (27\%) were males. Most of the study subjects were non-Saudis 57 (63\%) and 33 (37\%) were Saudis. The number of physicians and nurses was 31, 59 respectively. The majority of the health care workers 55 (61\%) were between the ages of 25 - 35 years old and 23 (26\%) were between the ages of 36 - 45 years old (Table 1).

When the studied subjects were asked about the cause of AIDS 30 (97\%) of physicians and 51 (86\%) of nurses knew the correct answer, which is virus, and $9(10 \%)$ of health care workers answered either bacteria or fungus. A total number of 18 (58\%) physicians and $36(61 \%)$ nurses thought that confidentiality of an AIDS patient was important, i.e. if there were two patients in one room and one of them had AIDS, it was not the right of the other patient to know about him which was correct (Table 2).

A very significant result $(\mathrm{p}<0.001)$ showed that $19(61 \%)$ physicians and $3(5 \%)$ nurses, knew that needle stick injury from an AIDS patient, would cause a $0.3 \%$ risk of transmitting the infection, while the majority had chosen 30\% risk of transmission [12]. A total of 66 (73\%) of HCWs in our institution knew that sexual practice was the most common mode of transmission HIV infection, while 14 (15\%) chose IV drug use, and 11 (12\%) chose blood product transfusion (Table 2).

Nurses gave more correct answers than physicians $(\mathrm{p}=0.01)$, when asked about the total number of AIDS patient in global UNAIDS reports in 2012, 58 (98\%) of nurses and 26 (84\%) of physician knew that the total number of AIDS patients globally were increasing, which was the correct answer [13]. All physicians and nurses $90(100 \%)$ knew that AIDS cannot be transmitted through air or by shaking hands. When the studied subjects were asked about air-borne isolation for an AIDS patient, 7 (12\%) of nurses and 2 (6\%) of physician believed that all AIDS patients admitted were supposed to be in an air-borne isolation (Table 2).

There was a significant difference between physician and nurses $(p=0.0003)$ about controlling the disease process in AIDS patients with an antiretroviral therapy. A total number of 60 (67\%) health care workers knew that antiretroviral therapy could control the disease process in AIDS patients, while the rest of the respondents, approximately 30 (33\%) health care workers, of which (26 nurses, 4 physicians) lacked this information. There was also a significant difference between physician and nurses when they were asked about the curability of AIDS $(p=0.03), 6(19 \%)$ of physicians and $3(5 \%)$ of the nurses believed that AIDS was curable. Finally, 69

\begin{tabular}{|c|c|}
\hline Gender & $\mathrm{N} / \%$ \\
\hline Male & $24(27 \%)$ \\
\hline female & $66(73 \%)$ \\
\hline \multicolumn{2}{|l|}{ Nationality } \\
\hline Saudi & $33(37 \%)$ \\
\hline Non-Saudi & $57(63 \%)$ \\
\hline \multicolumn{2}{|l|}{ Profession } \\
\hline Physician & $31(35 \%)$ \\
\hline nurse & $59(65 \%)$ \\
\hline \multicolumn{2}{|l|}{ Age } \\
\hline $20-24$ yrs & $2(2 \%)$ \\
\hline 25 - 35yrs & $55(61 \%)$ \\
\hline $36-45$ yrs & $23(26 \%)$ \\
\hline $46-55$ yrs & $8(9 \%)$ \\
\hline $56+\mathrm{yrs}$ & $2(2 \%)$ \\
\hline
\end{tabular}


Table 2. HIV/AIDS knowledge and attitude.

\begin{tabular}{|c|c|c|c|c|c|}
\hline Questions & Correct answers & Total $\mathrm{N}=90$ & Physician $\mathrm{N}=31$ & Nurse $\mathrm{N}=59$ & p-value \\
\hline $\begin{array}{l}\text { What is the cause of Acquired Immunodeficiency } \\
\text { syndrome (AIDS)? }\end{array}$ & virus & $81(90 \%)$ & $30(97 \%)$ & $51(86 \%)$ & 0.12 \\
\hline $\begin{array}{l}\text { In case of needle stick injury with an AIDS patient, } \\
\text { the risk of acquiring AIDS is? }\end{array}$ & $0.3 \%$ & $22(24 \%)$ & 19 (61\%) & $3(5 \%)$ & $<0.001$ \\
\hline $\begin{array}{l}\text { Confidentiality is important for patients with AIDS } \\
\text { (i.e. is the other patients in the room have the right } \\
\text { to know that another patient's is having AIDS)? }\end{array}$ & correct & $54(60 \%)$ & $18(58 \%)$ & $36(61 \%)$ & 0.79 \\
\hline $\begin{array}{l}\text { The commonest method of transmission of AIDS } \\
\text { currently is: (choose } 1 \text { answer) }\end{array}$ & Sexual practice & $66(73 \%)$ & $22(71 \%)$ & $44(75 \%)$ & 0.71 \\
\hline $\begin{array}{l}\text { According to UNAIDS global report on } 2012 \\
\text { the total number globally of AIDS patient is: }\end{array}$ & increasing & $84(93 \%)$ & $26(84 \%)$ & $58(98 \%)$ & 0.01 \\
\hline Can AIDS be transmitted by shaking hands? & no & 90 & 31 & 59 & \\
\hline AIDS can be transmitted through air? & no & 90 & 31 & 59 & \\
\hline $\begin{array}{l}\text { All AIDS patients admitted are supposed } \\
\text { to be in air-borne isolation? }\end{array}$ & no & $81(90 \%)$ & $29(94 \%)$ & $52(88 \%)$ & 0.42 \\
\hline $\begin{array}{l}\text { Can Antiretroviral therapy succeed in controlling } \\
\text { the disease process in AIDS patients? }\end{array}$ & yes & $60(67 \%)$ & $27(87 \%)$ & $33(56 \%)$ & 0.0003 \\
\hline Is AIDS curable? & no & $81(90 \%)$ & 25 (81\%) & 56 (95\%) & 0.03 \\
\hline $\begin{array}{l}\text { For a health care worker (HCW), treating an } \\
\text { AIDS patient is compulsory? }\end{array}$ & yes & 69 (77\%) & 23 (74\%) & 46 (78\%) & 0.69 \\
\hline
\end{tabular}

(77\%) of our health care workers knew that they were obligated to provide treatment for AIDS patients while 21 (23\%) of HCWs think they had the right to refuse providing care to AIDS patients (Table 2).

\section{Discussion}

This study explores the amount of knowledge the health care workers have about HIV/AIDS and their attitudes when encountering AIDS patients. It evaluates the knowledge and attitude by asking a focused questions about background basics of HIV/AIDS and managing and dealing with an AIDS patient, e.g. etiology, mode of transmission, confidentiality of the patient and management. This is very important information that the health care workers should be aware of.

The study showed that there were some deficits of knowledge between the health care workers both physicians and nurses but in general physicians are more aware compared to nurses. Nurses were able to identify the correct answer better than physicians when they were asked about confidentiality of an AIDS patients, the increase in the total number of AIDS patients globally and whether they were obligated to manage an AIDS patient or not.

One of the important questions was about the cause of AIDS, (10\%) of the health care workers chose either fungus or bacteria as the cause, while the correct answer is virus. It is worrying that $(10 \%)$ of our health care workers could not identify the correct answer for a basic question about AIDS; this indicates a serious lack of knowledge about AIDS. This deficit of knowledge was found in a study conducted in a public university in Riyadh, Saudi Arabia in 2010, about HIV/AIDS knowledge among male college students. They found more than (50\%) of the participants were unable to identify the correct answer for 6 out of 12 statements about HIV transmission [14]. This probably due to lack in public health awareness that the health care system is responsible for.

Another issue, the majority of the health care workers more than (70\%) did not know that the risk of acquiring HIV from a needle stick injury with an AIDS patient would be as little as (0.3\%). This might indicate the amount of fear from acquiring the human immunodeficiency virus when dealing with an AIDS patient. This also may explain why (23\%) of our HCWs with an equal number between physician and nurses, believe that dealing and treating HIV /AIDS patients is optional. Similar results were found in a South African study conducted in a tertiary hospital in KwaZulu-Natal in 2013. It shows that (51.8\%) of studied subjects are not able to identify the correct answer for the level of risk of HIV transmission following needle stick injury [15]. This deficit of knowledge would affect the attitude of the health care worker, when encountering AIDS patient, and it will raise their 
fear form acquiring the virus when managing an AIDS patient.

Nigeria has the third highest recorded number of people who are living with HIV/AIDS. There was a crosssectional study conducted where a questionnaire was administered and it included 210 adults. More than half of the respondents had adequate knowledge about HIV/AIDS, and the majority was willing to have voluntary counseling and testing. The majority of respondents (59\%) did not know the causative agent of AIDS; however, $71 \%$ and $64 \%$ of study subjects mentioning sexual activity and unscreened blood transfusion, respectively, as possible transmission routes which indicate a good knowledge about the routes of HIV transmission. The reasons for rejection of voluntary counseling and testing include fear of stigma, marital disharmony, incurable nature of the disease and treatment cost.

In Greece a cross-sectional study carried out in a nursing school of a Technological Educational Institute showed that overall student nurses had fairly good knowledge about HIV/AIDS as well as a positive attitudes towards AIDS people $(\mathrm{M}=70.39$; $\mathrm{SD}=18.43$; possible range 18 - 90). However, a few items presented contradictory results from the overall score of the knowledge scale. Of the respondents $39.8 \%$ believed that mosquitoes could transmit HIV and 38\% believed the virus could be transmitted via the toilet seat. $56.2 \%$ reported that vaccination could protect them from HIV/AIDS.

A good thing our study showed was that all the health care workers knew that HIV couldn't be transmitted by shaking hands or through air. Similar results were found in the South African study that more than (90\%) of health care workers knew that HIV couldn't live in the open air [15]. In our study there were also some gaps about controlling and managing AIDS patients, around (10\%) of the health care workers believed that AIDS was curable, and more than (30\%) of our HCWs did not know that antiretroviral therapy could control the disease process. Similar results were found in a study conducted in a public university in Riyadh, which showed $55 \%$ of the studied subjects believed that there was a cure for AIDS [14].

One of the limitations was that the research was conducted in one institution. We should include other institutions in the study. In addition, we should increase the sample size, and include other paramedical specialties in the study.

\section{Conclusion/Recommendation}

It was obvious from our study that there was some amount of general information and knowledge with our health care workers, but there were some gaps. However, an educational campaign will try to clear any misconception or misleading theories about HIV-infection, with our health care workers. Making brochures, posters, workshops about HIV/AIDS etiology, mode of transmission, confidentiality of the patient and management will increase the level of awareness.

\section{Conflict of Interests}

The authors declared no potential conflicts of interest with respect to the authorship and/or publication of this article.

\section{References}

[1] Douek, D.C., Roederer, M. and Koup, R.A. (2009) Emerging Concepts in the Immunopathogenesis of AIDS. Annual Review of Medicine, 60, 471-484. http://dx.doi.org/10.1146/annurev.med.60.041807.123549

[2] Kumar, P. and Clark, M. (2009) Clinical Medicine. 7th Edition, Elsevier Limited, Edinburgh.

[3] Prevention, C. (2015) Basic Statistics. http://www.cdc.gov/hiv/basics/statistics.html

[4] Central Department of Statistics \& Information (2014) http://www.cdsi.gov.sa/english/

[5] Mazroa, M.A., Kabbash, I.A., Felemban, S.M., Stephens, G.M., Al-Hakeem, R.F., Zumla, A.I. and Memish, Z.A. (2012) HIV Case Notification Rates in the Kingdom of Saudi Arabia over the Past Decade (2000-2009). PLoS ONE, 7, e45919. http://dx.doi.org/10.1371/journal.pone.0045919

[6] Al-Mazrou, Y.Y., Al-Jeffri, M.H., Fidail, A.L., Al-Huzaim, N. and El-Gizouli, S.E. (2005) HIV/AIDS Epidemic Features and Trends in Saudi Arabia. Annals of Saudi Medicine, 25, 100-104.

[7] Alrajhi, A.A., Halim, M.A. and Al-Abdely, H.M. (2004) Mode of Transmission of HIV-1 in Saudi Arabia. AIDS, 18, 1478-1480. http://dx.doi.org/10.1097/01.aids.0000131344.91536.64

[8] Hasnain, M. (2005) Cultural Approach to HIV/AIDS Harm Reduction in Muslim Countries. Harm Reduction Journal, 


\section{2, 23. http://dx.doi.org/10.1186/1477-7517-2-23}

[9] Logie, C.H., James, L., Tharao, W. and Loutfy, M.R. (2011) HIV, Gender, Race, Sexual Orientation, and Sex Work: A Qualitative Study of Intersectional Stigma Experienced by HIV-Positive Women in Ontario, Canada. PLoS Medicine, 8, e1001124. http://dx.doi.org/10.1371/journal.pmed.1001124

[10] Iliyasu, Z., Abubakar, I.S., Kabir, M. and Aliyu, M.H. (2006) Knowledge of HIV/AIDS and Attitude towards Voluntary Counseling and Testing among Adults. Journal of the National Medical Association, 98, 1917-1922.

[11] Ouzouni, C. and Nakakis, K. (2012) HIV/AIDS Knowledge, Attitudes and Behaviours of Student Nurses. Health Science Journal, 6, 129-150.

[12] Canadian Paediatric Society (2008) Needle Stick Injuries in the Community. Paediatrics Child Health, 13, $205-210$.

[13] UNAIDS (2012) UNAIDS Report on the Global AIDS Epidemic. http://www.unaids.org/en/resources/publications/2012/name,76121,en.asp

[14] Badahdah, A. (2010) Stigmatization of Persons with HIV/AIDS in Saudi Arabia. Journal of Transcultural Nursing, 21, 386-392. http://dx.doi.org/10.1177/1043659609360873

[15] Famoroti, T.O., Fernandes, L. and Chima, S.C. (2013) Stigmatization of People Living with HIV/AIDS by Healthcare Workers at a Tertiary Hospital in KwaZulu-Natal, South Africa: A Cross-Sectional Descriptive Study. BMC Medical Ethics, 14, S6. http://dx.doi.org/10.1186/1472-6939-14-S1-S6 


\section{Appendix}

\section{Questionnaire}

\section{Questionnaire of knowledge and attitude of health care workers toward AIDS patients in King Abdulaziz Medical City}

1. Sex:

Male

Female

2. Age:

$\square \quad 25$ - 35 years
$\square \quad 36$ - 45 years
$\square \quad 46$ - 55 years
$\square 56$ years and more

3. Profession:

Physician: $\square$ Yes $\square$ No
Nurse:
Laboratory
Technologist: $\square$ Yes $\square$ No $\square$ No
Dietician:
Social worker: $\square$ Yes $\square$ Nes $\square$ No

4. Nationality: $\square$ Saudi $\square$ Non-Saudi

5. What is the cause of Acquired Immunodeficiency syndrome (AIDS)?

$\square$ Bacteria $\quad \square$ Virus $\square$ Fungal element

6. In case of needle stick injury with an AIDS patient, the risk of acquiring AIDS is?

$\square 0.3 \% \quad \square 3 \% \quad \square 30 \%$

7. Confidentiality is important for patients with AIDS (i.e. is the other patients in the room have the right to know that another patient's is having AIDS)?

$\square$ Correct $\quad \square$ Incorrect

8. The commonest method of transmission of AIDS currently is: (choose 1 answer)

$\square$ IV drug use $\quad \square$ Blood product transfusion $\quad \square$ Sexual practices

9. According to UNAIDS global report on 2012 the total number globally of AIDS patient is:

$\square$ Increasing $\square$ Decreasing

10. Can AIDS be transmitted by shaking hands?

$\square$ Yes $\quad \square$ No

11. AIDS can be transmitted through air?

$\square$ Yes $\quad \square$ No

12. All AIDS patients admitted are supposed to be in air-borne isolation?

$\square$ Yes $\square$ No

13. Can Antiretroviral therapy succeed in controlling the disease process in AIDS patients?

$\square$ Yes $\quad \square$ No

14. Is AIDS curable?

Yes

No

15. For a health care worker (HCW), treating an AIDS patient is compulsory?

Yes

No 